\title{
Apprentice-trainer relationship and work group integration in the first months of an apprenticeship
}

\author{
Christof Nägele ${ }^{*}$ and Markus P. Neuenschwander
}

\author{
*Correspondence: \\ christof.naegele@fhnw.ch \\ University of Applied \\ Sciences and Arts \\ Northwestern Switzerland \\ School of Education, \\ Institute for Educational \\ Research and Development, \\ Center for Learning \\ and Socialization, \\ Obere Sternengasse 7, \\ 4502 Solothurn, Switzerland
}

\begin{abstract}
Background: Social integration is an important outcome of organizational socialization. It helps adolescents after transition to their first job to adapt rapidly to the new work and organizational situation. Positive social integration, especially a positive apprentice-trainer relationship and work group integration, helps the apprentices not only to overcome the uncertainties linked to this transition, but also to gain access to the resources needed for successful socialization and learning in the organization. The social integration develops within the first months in the new organization. First, we study how two indicators of social integration, namely the apprentice-trainer relationship and work group integration, develop over time. Second, we investigate how an individual's reliability, the perceived person-occupation fit, and organizational resources predict the level and development of the social integration within the first months in the new job.
\end{abstract}

Methods: The study is based on a longitudinal sample of 199 students in transition to work; that is, from compulsory school to apprenticeship at the upper secondary level. To estimate intra-individual development across time in the apprentice-trainer relationship and work group integration, latent growth curve analysis was used.

Results and conclusions: Both indicators of social integration-the apprenticetrainer relationship and work group integration-decrease over time. Pre-entry factors (a person's reliability and person-occupation fit) predicted the level of social integration but not the development. No effect of the apprentices' person-occupation fit and reliability could be found for the apprentice-trainer relationship. A negative effect of the person-occupation fit on work group integration was found. Organizational resources only predicted the initial level of the apprentice-trainer relationship. An individual's reliability and a strong person-occupation fit as before organizational entry help apprentices to become better socially integrated afterwards. These findings are discussed with reference to theoretical and practical implications.

Keywords: Organizational entry, Social integration, School-to-work transition, Apprenticeship

\section{Background}

The transition to one's first job is associated with ambiguities, and newcomers often feel like "strangers in a strange land" (Saks and Gruman 2012). Apprentices can overcome 
these uncertainties in the new organization by rapidly adapting and becoming socially integrated. Social integration helps to make sense out of the new situation (Korte 2010) and is a prerequisite for a successful socialization and learning in an apprenticeship (Nägele and Neuenschwander 2014). Despite the importance of the social integration of newcomers, little is known about how social integration develops over time during entry into an organization (Ashforth 2012). In this paper, we are interested to study the process of apprentices' social integration during organizational entry and predictors of the level and change of apprentices' social integration during organizational entry.

Becoming socially accepted and integrated is especially important for newcomers without prior organizational or work-related experiences, as is the case for apprentices in transition from compulsory school to education and training at the upper secondary level in Switzerland (Stalder and Nägele 2011). During organizational entry, apprentices cannot refer to their own work- and organization-related experiences, which would help them to adjust to the new situation. Although theories on social exchange and interpersonal relationships in organizations highlight that organizational socialization is a mutual process and should not be conceptualized as being solely the newcomers' responsibility (Schaubroeck et al. 2013), organizational socialization and learning depends substantially on the apprentices' willingness and capability to adapt rapidly. These attempts need to be supported by trainers and coworkers with the aim to integrate and instruct newcomers, which entails the social acceptance of the apprentices (Masdonati and Lamamra 2009). Socialization and learning in an apprenticeship is situated in a real-life situation and is therefore a social learning process (Wenger et al. 2002), with the apprentices being responsible for engaging in and contributing reliably to the work at hand. Additionally, the individual characteristics of an apprentice, e.g., her perceived pre-entry person-occupation fit (Nägele and Neuenschwander 2014) or his reliability, assiduity, or punctuality (Stalder and Stricker 2009), shape this socialization process. The organization can support a positive adjustment during organizational entry through their onboarding strategies (Klein and Polin 2012). It is important that newcomers get the information and guidance they need, which can be achieved by allocating enough resources to support them.

Learning at the workplace relies on a structured process of guidance, e.g., through helping the newcomers to understand workplace requirements or giving them access to important organizational and technological knowledge (Billett 2002). Furthermore, workplace trainers and coworkers need to design a workplace that allows the apprentice to learn (Hacker and Skell 1993). However, the apprentices' relationship to the workplace trainer and their coworkers is "at the heart" of socialization and learning in an apprenticeship (Masdonati and Lamamra 2009).

At present, studies addressing the transition from compulsory school to work that focus on the adjustment processes during organizational entry are rare. This paper contributes to the discussion on the organizational entry and socialization of inexperienced newcomers by investigating how two indicators of social integration, namely the apprentice-trainer relationship and work group integration, develop over time. It is analyzed how an apprentice's reliability, the perceived person-occupation fit, and organizational resources predict the level and development of the social integration within the first months of a new job. Based on the longitudinal data available for this study, we can 
model the level and change of the social integration and add to the discussion on the dynamics of the socialization process within the first five months of a new job.

\section{The apprentice-trainer relationship and work group integration as important proximal socialization outcomes in an apprenticeship}

Being accepted by insiders is an important proximal outcome of organizational socialization (Bauer and Erdogan 2012). For an apprentice, it is important that she or he develops a positive relationship with and is accepted by her or his workplace trainer; it is also important that she or he becomes integrated into the work group. In the long term, these relationships at work are positively related to socialization outcomes such as commitment, satisfaction, and turnover intentions (Nägele and Neuenschwander 2014; Bauer et al. 2007; Negrini et al. 2015). The important function of positive social integration can be seen in the development of affective commitment, which seems to be mediated by the development of trusting relationships with supervisors and coworkers (Lapointe et al. 2014). Relationship building is based on social exchange processes, which are typically conceptualized as mutual adaptation processes (Schaubroeck et al. 2013). However, in an apprenticeship, it is primarily the apprentice who has to adapt actively to organizational and occupational norms (Stalder and Schmid 2016). In this process, workplace trainers and coworkers help an apprentice to transfer knowledge and skills between different work situations and learning venues (Hinrichs 2014). It is a process of teaching and instructing the apprentice to help her or him get accustomed to the workplace (Lamamra and Duc 2015). Socialization and learning are based on informal and incidental task-related micro-level activities (de Saint-Georges and Filliettaz 2008) and on social activities (Haigh 2007). They are situated in a real-life context and based on reciprocal social processes (Billett 2000), which aim at eventually developing a shared conception of the work (Akkerman et al. 2007), and finally an occupational identity (Stalder and Nägele 2015; Klotz et al. 2014). Workplace trainers and coworkers also shape the career aspirations of their apprentices by assigning them more or less demanding work tasks and through the delivery of feedback (Hofmann et al. 2014). It is perceived support that helps a newcomer to adjust more easily to a new situation (Perrot et al. 2014). This support is delivered by workplace trainers and coworkers. A positive effect of this support on the socialization outcomes of apprentices depends on their individual perceptions of being accepted. It is the apprentices' feelings of attachment and inclusion that have an effect on socialization outcomes (Morrison 2002).

\section{Development of social integration}

The socialization process of apprentices starts long before organizational entry. During the vocational choice process at the lower secondary level, students explore different occupations and apply for several apprenticeship places in training companies (Herzog et al. 2006). This process helps students to develop a vocational orientation (Büchter et al. 2014) and also to find an apprenticeship that fits their abilities, interests, and personality (van Vianen and De Pater 2012; Nägele and Neuenschwander 2015). In fact, most students find a good-fitting apprenticeship (Neuenschwander et al. 2012) and are highly satisfied with their occupational choice and the training organization that employed them (Berweger et al. 2013; Meyer et al. 2000). Even if it is hard to anticipate the social 
situation in the organization reliably before or shortly after organizational entry (van Vianen and De Pater 2012), we suppose that apprentices generalize their overall positive assessments of their vocational choice to their perceptions of the apprentice-trainer relationship and work group integration.

After organizational entry, apprentices will readjust their assessments of their social integration based on the new information and their own experiences. Bauer et al. (2007) report that, based on a meta-analysis, social acceptance decreases within the first 6 months then increases until the ninth month, when it decreases again. KammeyerMueller et al. (2013) report that both supervisor support and coworker support decrease over time after organizational entry. However, adjustment processes can have overall different shapes from high to low or vice versa, or they can be non-linear, e.g., high in the beginning, then dropping and rising again after some time. It is also not necessarily the case that all newcomers adapt at the same rate and follow the same pattern. Inter-individual differences can create a multitude of different developmental patterns (Solinger et al. 2013). For example, we found differential patterns in the development of personoccupation fit in apprentices (Nägele and Neuenschwander 2015). However, still little is known about the temporal factors of the adjustment process (Ashforth 2012), as temporal factors often seem to be neglected in organizational research (Sonnentag 2012). It is unclear whether the social integration increases, stays stable or increases with time. Apprentices will assess their social integration high after organizational entry because of their vocational choice process and the onboarding strategies of the training companies (Neuenschwander et al. 2012). As the apprentices might initially not be aware of negative social aspects in the training company, it is most likely that their perception of being socially integrated will diminish.

\section{Hypothesis 1}

The level of apprentice-trainer relationship (H1.ai) and work group integration (H1.bi) is highest after organizational entry. The level of the apprentice-trainer relationship (H1. as) and work group integration (H1.bs) decreases over time.

\section{Predictors of the level and development of the apprentice-trainer relationship and work group integration}

Successful organizational socialization depends on pre-entry factors such as the generic skills of the apprentices, their person-occupation fit, and organizational resources (Bauer and Erdogan 2012).

Generic or transferable skills play an important role in the transition from school to work. One expectation of workplace trainers is that a new apprentice should be reliable and conscientious in terms of being decent, punctual, and honest (Stalder 2000; Stalder and Stricker 2009; Ehrenthal et al. 2005; Schmid and Storni 2004; Dornmayr et al. 2007). As apprentices work from the first day of their apprenticeship in real-life situations, trainers and coworkers need to rely on the apprentice, e.g., she or he must be punctual. An applicant's reliability therefore becomes an important selection criterion. Furthermore, a person who is known to be reliable will also be less likely to show counterproductive behaviors (Spector et al. 2006). As reliability is a strong and shared value among the training companies, apprentices need to adopt these values. Accordingly, apprentices 
who share these values will have a better chance of being accepted by the other members of the work group (Joardar and Matthews 2010). A reliable apprentice is expected to integrate more easily into the company and work group, to master tasks more efficiently, and to become goal oriented in a shorter period of time. We expect reliable apprentices to have fewer difficulties while integrating into the new organizations.

\section{Hypothesis 2.1}

Apprentices' reliability will have a positive effect on the level and development of the apprentice-trainer relationship (H2.1ai H2.1as) and on the level and development of work group integration (H21.bl, H2.1bs).

An adequate person-occupation fit will facilitate organizational adjustment (Cable and Judge 1996; Kristof-Brown et al. 2005) and reduce the risk of dropping out of the apprenticeship (Stalder and Schmid 2016; Schmid and Stalder 2012). Before organizational entry, apprentices establish a pre-entry person-occupation fit, which results from their vocational choice process (Nägele and Neuenschwander 2014). Vocational choice processes are influenced in multiple ways by the family, the school, and the socioeconomic situation. Against this background, vocational decisions are based on the balancing of individual interests, values, and expectations (Eccles 2005; Neuenschwander et al. 2012).

The positive effect of pre-entry fit perceptions on the adjustment process can only be expected if (high) fit expectations are confirmed after organizational entry (Vandenberg and Scarpello 1990; Irving and Meyer 1999). Apprentices with higher levels of pre-entry person-occupation fit not only reported being better socially integrated in the first month of apprenticeship (Nägele and Neuenschwander 2014), but they also reported that their person-occupation fit remained unchanged or even improved during the first months of the apprenticeship (Nägele and Neuenschwander 2015). The occupational expectations of these apprentices have been met. As apprentices have only little information on the social situation of their new organizations, a positive perceived pre-entry person-occupation fit will be generalized to the perception of the social situation. We expect that the pre-entry perceived person-occupation fit will have a positive effect on the development of social integration.

\section{Hypothesis 2.2}

Apprentices' perceived pre-entry person-occupation fit has a positive effect on the level and development of the apprentice-trainer relationship (H2.2ai, H2.2as) and on the level and development of work group integration (H2.2bi, H2.2bs).

Organizational resources determine how many apprentices are assigned to a workplace trainer. Workplace trainers have an important role in guiding apprentices. Guiding an apprentice takes time, but time is not always available (Filliettaz 2010). One factor that determines the time available is the number of apprentices a workplace trainer is tasked to supervise. If a workplace trainer has many apprentices to supervise, she or he will have less time for each apprentice. We expect that, in a situation where a workplace trainer has fewer apprentices to supervise, the apprentice-trainer relationships will be better. 


\section{Hypothesis 3}

A higher number of apprentices to supervise will have a negative effect on the level and development of the apprentice-trainer relationships ( $\mathrm{H} 3 \mathrm{i}, \mathrm{H} 3 \mathrm{~s})$

The conceptual model is in Fig. 1. This model is based on the process models of organizational socialization (Kammeyer-Mueller and Wanberg 2003).

\section{Methods}

\section{Sample and procedure}

Our data stems from a longitudinal study on socialization effects in the transition from school to work in the German-speaking part of Switzerland (Neuenschwander and Nägele 2014). Apprentices were asked to participate in the study in their last year of compulsory school at the lower secondary level if they planned to start directly with their apprenticeship training at the upper secondary level and if they agreed to complete an online questionnaire at the end of compulsory school and successively every month during the first six months in iVET. Initially, 550 students (grade 11, 15-16 years old) agreed to participate in the longitudinal study (Neuenschwander and Nägele 2014). The survey at the end of compulsory school was conducted in the classroom. After the transition from school to the apprenticeship, the apprentices were scattered at many different small- and medium-sized companies. Therefore, the invitations were sent to the participants' private email addresses to give them access to an online questionnaire. Additionally, a questionnaire was sent to all of the participating apprentices' organizations. This questionnaire was returned by 244 organizations. The selected sample for the analyses presented in this study is $N=199$. The selection criteria were as follows: (1)

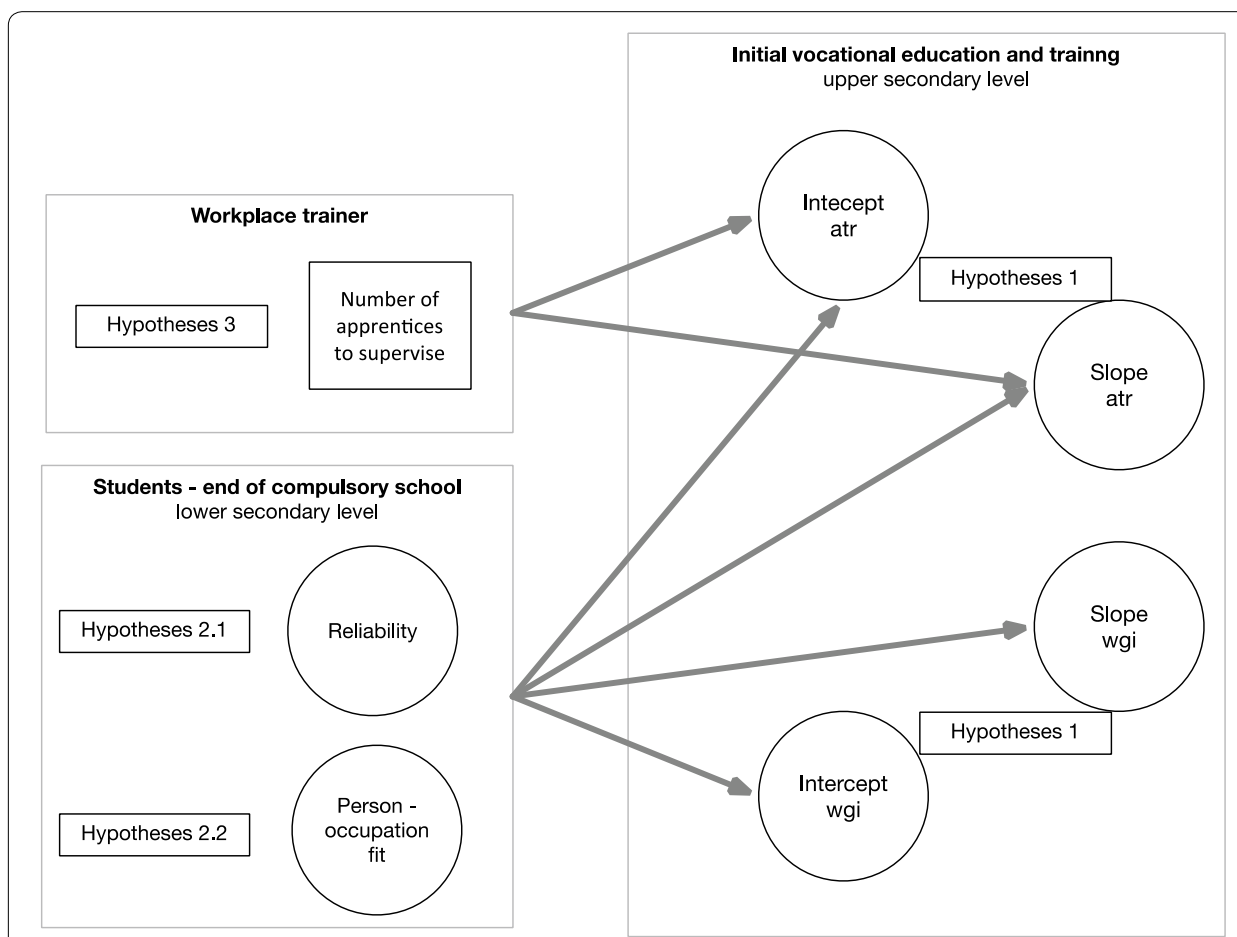

Fig. 1 Conceptual model. atr apprentice-trainer relationship, wgi work group integration 
workplace trainers and apprentices filled in the questionnaires and the answers could be matched, and (2) the apprentice filled in at least the first questionnaire (at school), the last questionnaire in the fifth month of the apprenticeship, and one of the three questionnaires in the second, third, or fourth month. There were 128 (64 \%) female and 71 male (36\%) apprentices who participated, with an average age of $M=16.1$ years (11th grade), $S D=.56 ; 87$ (44\%) female and 110 (56\%) male workplace trainers participated. From the 199 participating apprentices and their workplace trainers, 117 (59\%) worked in small organizations (up to 49 employees), 46 (23\%) worked in medium-sized organizations (up to 249 employees), and 36 (18 \%) worked in bigger organizations. The sample attrition was mainly due to the following effects. After compulsory school, some participants were no longer motivated to participate in the study as they had to fill in the questionnaire in their spare time and not all training companies took part in the study.

\section{The Swiss apprenticeship}

At the end of compulsory school (grade 11, age 15), most adolescents in Switzerland continue their further education in a company-based apprenticeship. An apprenticeship in a company or organization is the most frequently chosen type of vocational education and training (SERI 2015). In an apprenticeship, apprentices are educated and trained in a specific occupational field in which they eventually become professionals and experts (Rauner et al. 2000, 2015; Stalder and Nägele 2011). Learning at work is supplemented by education at vocational schools and inter-organization trainings. Vocational education and training gives access to higher education and lifelong learning. An apprenticeship lasts 2, 3, or 4 years, depending on the occupation and the affordance of the apprenticeship. The completion of iVET is crucial for a successful occupational career and a successful entry into the labor market (Schafer and Baeriswyl 2015). A successful entry into an apprenticeship is an important first step in the occupational career of an adolescent. After compulsory school, the new apprentice enters the organization as a coworker and learner, without any prior work experience or specific occupational knowledge.

\section{Measures}

The apprentice-trainer relationship was measured monthly after organizational entry with three items from Neuenschwander et al. (Neuenschwander et al. 1998) (e.g., "I am happy to talk about my personal problems with my workplace trainer."). They were measured on a scale from 1, "I do not agree at all," to 6, "I fully agree". It is the apprentices' self-report measure. Cronbach's alphas are as follows: 1st month $\alpha=.77$, 2nd month $\alpha=.85$, 3rd month $\alpha=.82$, 4th month $\alpha=.76$, and 5th month $\alpha=.80$.

Work group integration was measured monthly after organizational entry with three items adapted from Morrison (2002) reflecting a newcomer's feelings of attachment and inclusion. (e.g., "I feel comfortable around my coworkers"). These items were translated into German. They were measured on a scale from 1, "I do not agree at all," to 6, "I fully agree". It is the apprentices' self-report measure. Cronbach's alphas are as follows: 1st month $\alpha=.71,2$ nd month $\alpha=.73$, 3rd month $\alpha=.67$, 4th month $\alpha=.77$, and 5th month $\alpha=.79$.

The apprentice's reliability was measured at the end of compulsory school with three items based on Neuenschwander and Frank (2009) (e.g., "I am trustworthy"). It was 
measured on a scale from 1, "Not at all true," to 6, "Completely true". It is the apprentices' self-report measure. Cronbach's alpha is $\alpha=.66$.

The person-occupation fit was measured at the end of compulsory school with three items from Neuenschwander and Frank (2009). The items describe how well the occupation fits in terms of the individual's personality and abilities (e.g., "My apprenticeship training fits my personality"). It was measured on a scale from 1, "I do not agree at all," to 6, "I fully agree". It is the apprentices' self-report measure. Cronbach's alpha is $\alpha=.76$.

This measure is from the questionnaire for workplace trainers. Workplace trainers were asked how many apprentices they were tasked with supervising. The responses were 1 for "one apprentice," $N=43$ (22 \%), 2 for "two or three apprentices," $N=70$ (35\%), 3 for "four to nine apprentices," $N=54$ (27 \%), and 4 for "ten or more apprentices," $N=32$ (16\%). The mean was $M=2.4, S D=1.0$.

\section{Analytical procedure}

To estimate intra-individual development across time in the apprentice-trainer relationship and work group integration, latent growth curve analysis was used. We applied growth curve modeling using Mplus 7.11 (Muthén and Muthén 1998-2012). The full information maximum likelihood (FIML) procedure included in Mplus was used to deal with missing data, which leads to a more reliable and less biased estimation than other methods (Schafer and Graham 2002). Latent growth curve analysis accounts for individual differences in the responses at the first measurement (intercept), and the change of the participants' responses over time (slope). A latent growth model results in an estimation of the average initial level, the average growth rate, and the variation across individuals for initial level and growth rate. The combination of two latent growth models, known as a multivariate latent growth model, allows for the investigation of associations between initial levels and growth rates of the apprentice-trainer relationship and the work group integration (Duncan et al. 2006).

Several steps were followed to analyze the data. First, we tested the apprentice-trainer relationship and work group integration for measurement invariance. Second, we estimated growth curve models for the apprentice-trainer relationship and work group integration. Third, we predicted the intercept and slope of the apprentice-trainer relationship and work group integration using a set of variables describing the person and the person-occupation fit (11th grade) and factors describing the training organization. We report the model fit according to $\mathrm{Hu}$ and Bentler $(1999,1998)$ and Boomsma $(2000)$. They recommend that for sample sizes such as ours, good fit is indicated if the comparative fit index (CFI) and Tucker Lewis index (TLI) are greater than or equal to .95, the root mean square error of approximation (RMSEA) is less than or equal to .06, and the standardized root mean square residual (SRMR) is less than or equal to .08.

\section{Results}

\section{Measurement invariance tests}

To test for longitudinal measurement invariance, we separately calculated a configural invariance model for the apprentice-trainer relationship and work group integration from the 1st to the 5th month of the apprenticeship (van de Schoot et al. 2012). In this model, all factors had estimated variances and covariances, but the factor means were 
fixed to 0. Second, we tested for weak factorial (metric) invariance, holding all factor loadings equal across time. Finally, we tested for strong factorial (scalar) invariance by additionally holding all intercepts equal over time except for the intercept of the first measurement. Both measures-apprentice-trainer relationship and work group integration-meet the criteria for strong factorial (scalar) invariance. That is, changes in the mean reflect a change in apprentice-trainer relationship and work group integration. The results are described in Table 1.

\section{Descriptive results}

Table 2 shows the univariate descriptive statistics of all variables in the study. To examine both the apprentice-trainer relationship and work group integration and the predictors in the analyses, we had to ensure an appropriate ratio of the sample size to the parameters estimated. We used the scale mean to indicate the latent factors (i.e., the apprentice-trainer relationship and work group integration) across the five months (Schaubroeck et al. 2013). The scale means were calculated based on the unstandardized factor loadings of the measurement model with strong factorial invariance. These adjusted means were used in all subsequent analyses to ensure an appropriate samplesize-to-parameter-estimate ratio.

\section{Latent growth model with apprentice-trainer relationship and work group integration}

We calculated a multivariate latent growth model for the apprentice-trainer relationship and work group integration. As hypothesized, a linear trend was modeled. As both measures were self-report measures of the apprentices, the intercepts of the apprenticetrainer relationship and work group integration were allowed to correlate. The model fit the data well, $\chi^{2}=77.070, d f=41, p<.01$, CFI $=.973$, TLI $=.970$, RMSEA $=.066$, $\mathrm{SRMR}=.073$. For the apprentice-trainer relationship the mean intercept was 8.900 (.560), $p<.01$, and the mean slope was -.301 (.116), $p<.01$. The intercept and slope did not correlate, $r=-.194$ (.120), n.s., implying that the initial level of the apprenticetrainer relationship and the negative growth were independent. For work group integration the mean intercept was 10.079 (.653), $p<.01$, and the mean slope was $-.328(.119)$, $p<.01$. The intercept and slope did not correlate, $r=-.027$ (.123), n.s., implying that the initial level of work group integration and the negative growth were independent.

Table 1 Goodness-of-fit indices for measurement models of the apprentice-trainer relationship and apprentice's work group integration

\begin{tabular}{lllllllll}
\hline Measurement models & $\mathbf{X}^{\mathbf{2}}$ & $\boldsymbol{d f}$ & ${\text { Diff } \mathbf{X}^{\mathbf{2}}}$ & Diff $\boldsymbol{d f}$ & $\boldsymbol{p}$ & TLI & RMSEA & SRMR \\
\hline Apprentice-trainer relationship & & & & & & & & \\
$\quad$ Configural invariance model & 81.139 & 50 & - & - & & .966 & .056 & .043 \\
Weak factorial (metric) invariance & 90.013 & 58 & 8.87 & 8 & .353 & .970 & .053 & .061 \\
Strong factorial (scalar) invariance & 100.712 & 65 & 10.70 & 7 & .152 & .970 & .053 & .058 \\
Apprentice's work group integration & & & & & & & & \\
$\quad$ Configural invariance model & 107.079 & 50 & - & - & & .927 & .076 & .061 \\
Weak factorial (metric) invariance & 115.201 & 58 & 8.12 & 8 & .422 & .937 & .070 & .084 \\
Strong factorial (scalar) invariance & 120.924 & 65 & 5.72 & 7 & .570 & .945 & .066 & .088 \\
\hline
\end{tabular}




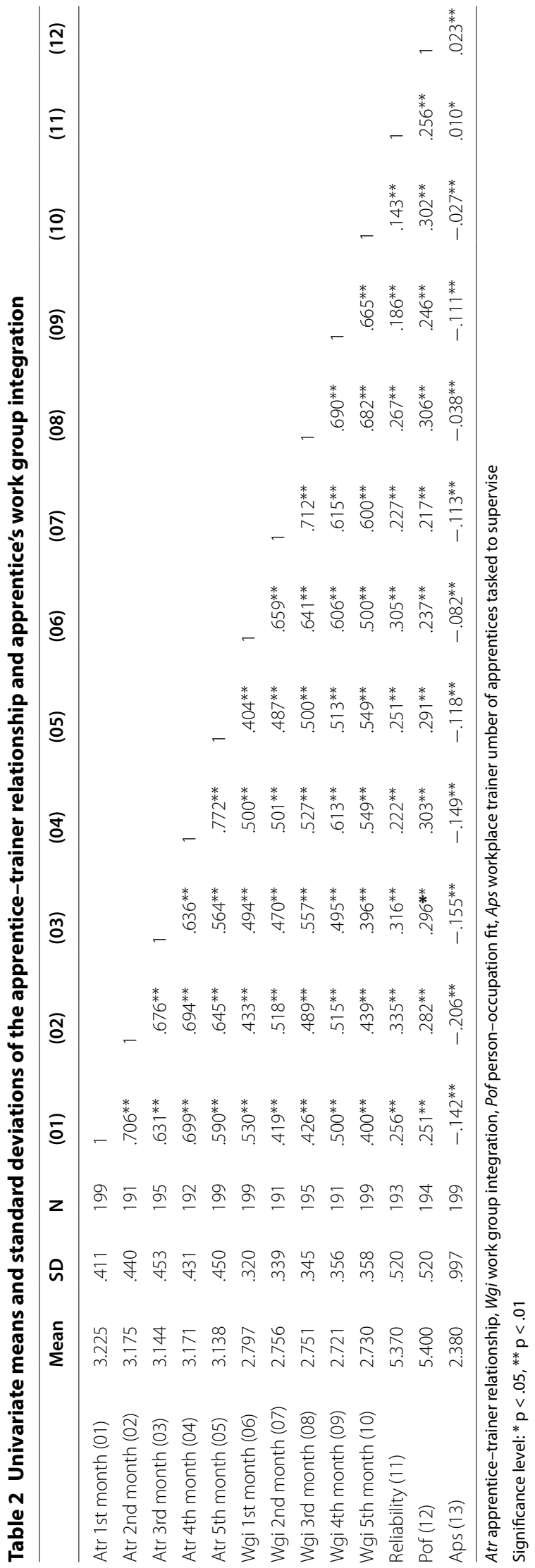


The two intercepts of the apprentice-trainer relationship and work group integration were strongly correlated, $r=.680(.058), p<.01$, and so were the slopes of the apprentice-trainer relationship and work group integration, $r=.635$ (.163), $p<.01$. The level of the apprentice-trainer relationship and work group integration were correlated with each other in the beginning and later on as well, as there was a positive correlation between the slopes of the apprentice-trainer relationship and work group integration. There were significant variances in the intercept and slope of the apprentice-trainer relationship-intercept .128 (.016), $p<.01$, slope .003 (.001), $p<.01-$ and the work group integration-intercept .087 (.013), $p<.01$, slope .023 (.007), $p<.01$.

Hypothesis 1 was confirmed, as the level (intercept) of the apprentice-trainer relationship (H1ai) and the level of work group integration (H1bi) were highest after organizational entry, and as there was a decrease (negative slope) for the apprentice-trainer relationship (H1as) and work group integration (H1bs) over time.

We tested alternative models with non-linear slopes. However, none of these models had a better fit than the model presented above. That is, we can show a linear decrease in the social integration within the first months of the apprenticeship.

\section{Predicting intercept and slope of the apprentice-trainer relationship and work group integration}

This model showed a good fit, $\chi^{2}=155.033, d f=114, p<.05$, CFI $=.975$, TLI $=.970$, RMSEA $=.043$, SRMR $=.066$. The intercept in the apprentice-trainer relationship was predicted by the apprentices' reliability, .311 (.094), $p<.01$ (Hypothesis 2.1ai confirmed), the apprentices' person-occupation fit, .235 (.091), $p<.01$ (Hypothesis 2.2ai confirmed), and the number of apprentices under the supervision of a workplace trainer, -.144 (.063), $p<.05$ (Hypothesis 3ai confirmed). The slope of the apprentice-trainer relationship could not be predicted by any of the predictors in the model (Hypotheses 2.1as, 2.2as, and 3s not confirmed). The intercept in work group integration was predicted by reliability, .361 (.095), $p<.01$ (Hypothesis 2.1 bi confirmed), and students' person-occupation fit, .185 (.095), $p<.05$ (Hypothesis 2.2bi confirmed). The slope of work group integration could be predicted by the apprentices' reliability, -.385 (.139), $p<.01$ (Hypothesis 2.1bs confirmed) and by the apprentices' person-occupation fit, 295 (.135), $p<.05$. Hypothesis $2.2 \mathrm{bs}$ was not confirmed, as the factor loading was positive and the slope was negative.

The correlation between the initial level (intercept) of the apprentice-trainer relationship and work group integration in the first month of the apprenticeship was $r=.511$ (.080), $p<.01$. The two slopes were not correlated, $r=.348$ (.189), n.s. All independent variables were correlated, as reported in Table 3 . The total explained variance with all variables in the model was $23 \%$ in the intercept and $4 \%$ in the slope of the apprenticetrainer relationship; for work group integration, it was $21 \%$ in the intercept and $16 \%$ in the slope. The hypothesized significant effects are presented in Fig. 2. Details of the analysis are presented in Table 3. 
Table 3 Detailed results of the latent growth analysis

\begin{tabular}{|c|c|c|c|c|c|c|}
\hline & $\begin{array}{l}\text { Estimate } \\
\text { intercept }\end{array}$ & S.E. & $\begin{array}{l}\text { One-tailed } \\
\text { p value }\end{array}$ & $\begin{array}{l}\text { Estimate } \\
\text { slope }\end{array}$ & S.E. & $\begin{array}{l}\text { One-tailed } \\
\text { p value }\end{array}$ \\
\hline \multicolumn{7}{|c|}{ Apprentice-trainer relationship } \\
\hline Reliability & .311 & .0904 & $.000^{* *}$ & -.139 & .153 & .182 \\
\hline $\begin{array}{l}\text { Pre-entry person- } \\
\text { occupation fit }\end{array}$ & .235 & .091 & $.005^{* *}$ & .199 & .144 & .084 \\
\hline $\begin{array}{l}\text { Number of } \\
\text { apprentices }\end{array}$ & -.144 & .063 & $.011^{*}$ & .046 & .108 & .335 \\
\hline Explained variance & $23 \%$ & & & $4 \%$ & & \\
\hline \multicolumn{7}{|l|}{ Work group integration } \\
\hline Reliability & .361 & .095 & $.000^{* *}$ & -.385 & .139 & $.003^{* *}$ \\
\hline $\begin{array}{l}\text { Pre-entry person- } \\
\text { occupation fit }\end{array}$ & .185 & .095 & $.026^{*}$ & .295 & .135 & $.015^{*}$ \\
\hline Explained variance & $21 \%$ & & & $16 \%$ & & \\
\hline
\end{tabular}

\section{Discussion and conclusions}

In this article, we first investigated how the apprentice-trainer relationship and work group integration develop over time. Second, we investigated how the apprentices' reliability, their perceived person-occupation fit, and organizational resources predict the level and development of the social integration within the first 5 months of an apprenticeship.

We found that the apprentices' assessment of the apprentice-trainer relationship and work group integration were, as expected, most positive after organizational entry (1st month of the apprenticeship), followed by a negative linear decrease in the apprenticetrainer relationship and work group integration (2nd to 5th month of the apprenticeship) (Hypotheses 1ai, 1as, 1bi, and 1bs confirmed). This is in line with other studies that found high levels of social integration at the beginning of a new job, followed by a decrease during the first months (Bauer et al. 2007). We found that the decrease over time was independent of the initial level of the perceived social integration, as neither the slope for the apprentice-trainer relationship nor the slope of work group integration were correlated with the level of the respective indicator. The perceived social integration decreased for all apprentices in the first months of their apprenticeships. As the apprentices became more familiar with their new situations and got to know their workplace trainer and coworkers better, they started to correct their initial assessment, which was primarily based on information gathered during the selection process and the onboarding activities during their first month in the training company.

Apprentices who described themselves as being reliable (11th grade) reported after organizational entry (1st month of the apprenticeship) a better apprentice-trainer relationship and work group integration. They also developed a better work group integration (1st to 5th month). These results are as expected. Being reliable is a strong value in organizations, and apprentices who share the same attitude adjust more easily to the new setting. However, we found that the apprentices' reliability did not have an effect on the development of the apprentice-trainer relationship. This non-effect is puzzling. Most likely, other factors become more important for predicting the development of the apprentice-trainer relationship. It may well be that reliability can predict the level and 


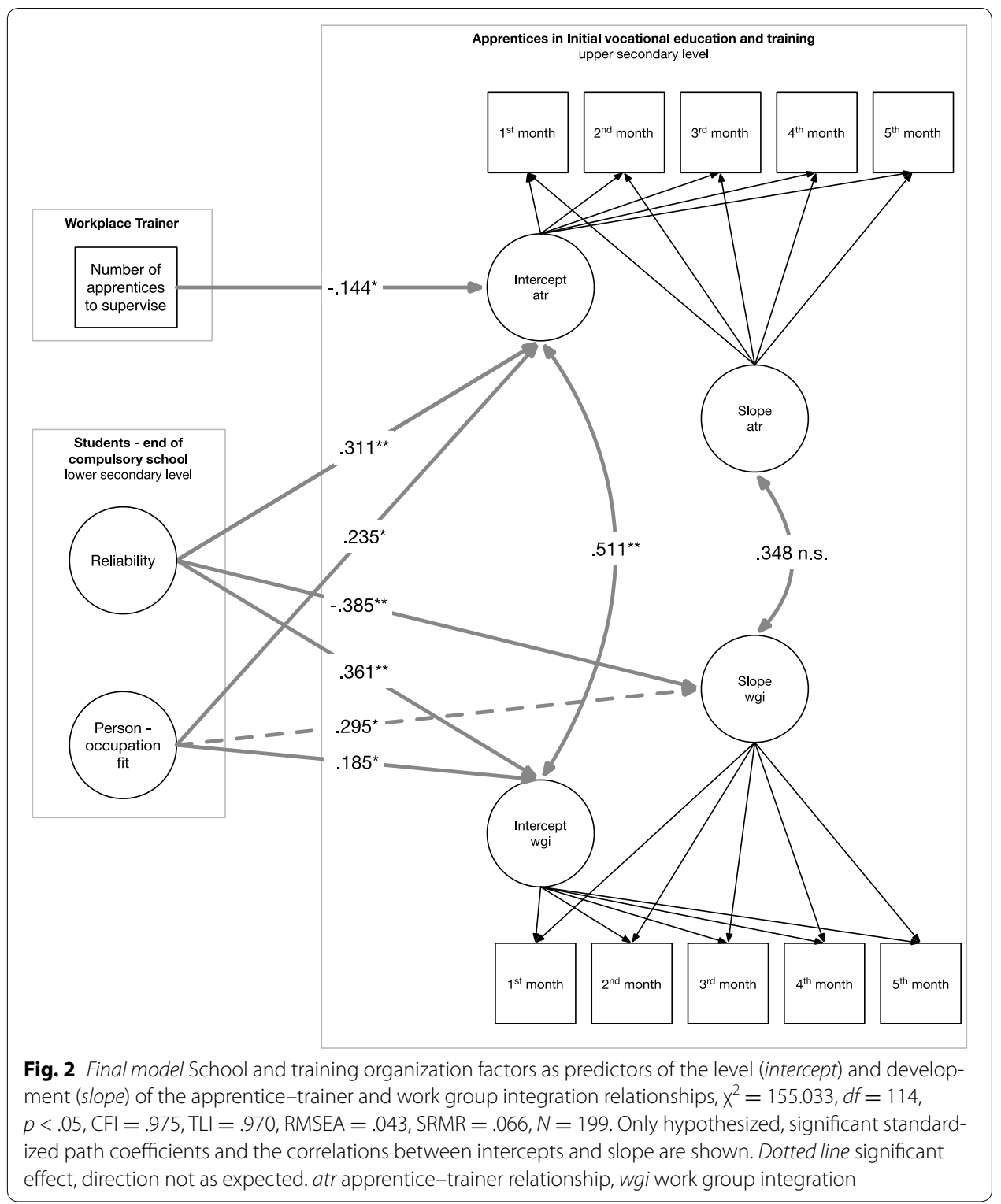

development of the social relationship in the very beginning. As soon as other information is available, however, reliability will become less relevant.

The apprentices' pre-entry person-occupation fit had, as hypothesized, a positive effect on the apprentice-trainer relationship and work group integration (Hypotheses 2.2ai and 2.2bi confirmed). However, the perceived person-occupation fit did not have an apparent effect on the development of the apprentice-trainer relationship, while the effect on the work group integration was negative, as the path coefficient was positive and the slope negative (Hypotheses 2.2as and 2.2bs not confirmed). We did not expect that high levels of person-occupation fit could have a negative effect on the work group integration. In prior studies, we found that person-occupation fit had an overall strong positive effect on socialization outcomes and that, overall, the person-occupation fit increased over time (Nägele and Neuenschwander 2015). The negative effect of a strong person-occupation fit on work group integration could be explained by at 
least two factors. First, although apprentices know a lot about their occupation before organizational entry, they know little about the training company (Stalder and Schmid 2006). The apprentices' initial assessments of their work group integration is most likely biased by an overall positive evaluation of the changing environment in transition from school to work and by an overall positive evaluation of the occupation and training company (Neuenschwander et al. 2012). These first experiences are typically positive, as there are specific onboarding programs for apprentices, and they get a positive and warm welcome. Apprentices need to generalize their positive perceptions of the occupation and the positive experiences during organizational entry because they have almost no other information to evaluate the social situation at the beginning of apprenticeship (van Vianen and De Pater 2012). Second, the perception of the apprenticeship is, in the beginning, mainly a perception of the occupation and not of the training company. The vocational choices of the adolescents are focused on finding the best-fitting occupation, especially in the group of those apprentices that starts with an apprenticeship directly after compulsory school. In this process, they develop a picture of the occupation that is not necessarily shared by the coworkers in the work group. This will lead apprentices to assess their social integration more critically and differentially. While the apprentices are still convinced that they have chosen a good-fitting occupation, they start to see their social integration less positively, an effect that is especially strong in adolescents with a very strong pre-entry person-occupation fit. This might be explained by several reasons. These apprentices probably expected something different from working in a work group in an organization, or they were not accepted or could not integrate themselves into the work group.

As expected, the number of apprentices to supervise had a negative effect on level of the the apprentice-trainer relationship, but we found no effect on the development of the apprentice-trainer relationship (Hypothesis 3ai confirmed; Hypothesis 3as not confirmed). Overall, the pre-entry factors had no effect on the development of the apprentice-trainer relationship. This is most likely due to differential processes in the apprentices' relationship building with the workplace trainers and the colleagues in the work groups. One of the roles of a workplace trainer is to evaluate the apprentice(s). In the interaction between the apprentice and the trainer, the apprentice's current behavior and her or his progress becomes a much stronger topic than in discussions with the colleagues in the work group. This might be a reason why the pre-entry factors do not predict the development of the apprentice-trainer relationship but they do for work group integration.

\section{Practical implications}

We found that apprentices assess their social integration in the beginning of their apprenticeship very positively. This is in line with findings of other studies describing the passage from school to work as a smooth transition and positive experience for a majority of the apprentices (Neuenschwander et al. 2012). This positive finding can be seen as a result of the big efforts made by schools on the lower secondary level and the training companies in supporting apprentices to find a fitting apprenticeship.

However, social integration decreases during the first months in apprenticeship for all apprentices, and regardless of their initial level of social integration. As it is is hard for newcomers to anticipate the social situation in an organization before becoming 
a member of the organization (van Vianen and De Pater 2012), we assume that the decrease in the social integration reflects a correction of the initial assessment. This new assessment is based on newly available information from within the organization and own experiences from working together with the new colleagues in the work group. Nevertheless, training-companies and apprentices should be attentive if there is a huge and constant decrease in the assessment of the social integration, as these might indicate a negative development which can result in dropping out from apprenticeship (Berweger et al. 2013; Stalder and Schmid, 2016). Consequently, training companies should be careful to closely monitor the development of the apprentice's social integration and to be ready to intervene if necessary. Reliable apprentices assess their social integration more positively. Apprentices should be aware that being reliable is an important aspect in becoming accepted by the members of the work group.

The effect of the person-occupation fit on the development of the workgroup integration was not as expected, as apprentices with a very high person-occupation fit experience a higher decrease in their workgroup integration. It might be that apprentices with a very high person-occupation fit hold at the same time also very high, but unrealistic expectations towards their social integration in the work group. A more realistic insight in how it is to work in the training-company and the workgroup, given during the selection process and the induction phase, could be helpful to minimize this effect.

\section{Limitations}

In this study, an individual's reliability and occupational fit were measured before organizational entry and treated as predictors. It would be interesting to see how these aspects change over time, as there is a reciprocal relationship between the apprentice and personality development during an apprenticeship (Schallberger et al. 1984). We see also that the perceived fit might change slightly over time (Nägele and Neuenschwander 2015). The data available limit the analyses, as reliability was only measured before organizational entry. A larger data set and a longer observation period would be needed to address these questions.

This study is based on a rather small sample size of a selected group of apprentices who started their apprenticeships directly after compulsory school. This article is based on self-reported data from apprentices. These findings should be replicated with a larger sample size, also taking into account different organizations' onboarding scenarios as well as the different perspectives of apprentices and workplace trainers.

\section{Implications for future research}

The theoretical framework for this study comes from literature on the organizational socialization of adults (Kammeyer-Mueller and Wanberg 2003; Bauer and Erdogan 2012). Within this theoretical framework, social integration, operationalized by the apprentice-trainer relationship and work group integration, is an important proximal socialization outcome and a precondition for successful organizational adjustment. We argued that the social integration of apprentices is even more important, as their socialization and learning rely on establishing supportive and lasting social relationships (Masdonati and Lamamra 2009). We could show that social integration is an important predictor for distal socialization outcomes, namely a high commitment to the 
occupation and the organization (Nägele and Neuenschwander 2014). We have also evidence from several studies that social problems in an apprenticeship raise the individual risk for non-linear pathways through an apprenticeship or for drop-outs (Berweger et al. 2013; Schmid and Stalder 2012). As social integration is crucial for an apprentice's socialization and learning, it is important to know how social integration develops and changes during organizational entry and how this development can be explained by pre-entry factors related to the school context or to effects of the company's onboarding strategies. This paper adds to this discussion by highlighting the important role of an apprentice's reliability, which seems to have an effect primarily at the very beginning of a relationship. Researchers should take a closer look at the function of an apprentice's reliability, as this is what many training companies are asking for. Furthermore, a strong person-occupation fit helps apprentices to become better socially integrated. However, based on the data available, the negative effect on the development of work group integration could not be explained. It would be interesting to know the conditions that lead to this effect. Several explanations seem plausible, including disappointment with the work group, the number of coworkers, the development of differential relationships, the characteristics of individual members of the work group, or simply temporal factors, as the apprentices get to know the members of the work group after they have gotten to know the workplace trainer.

\section{Authors' contributions}

$\mathrm{CN}$ wrote the paper based on data from a project which was initiated, conceived, designed and coordinated by MN. Both authors discussed, reviewed and revised the paper. All authors read and approved the final manuscript.

\section{Acknowledgements}

This study was supported by the State Secretariat for Education, Research, and Innovation (SERI). The interpretations, conclusions, and recommendations are those of the authors and do not necessarily represent the views of the SERI.

\section{Competing interests}

The authors declare that they have no competing interests.

Received: 8 November 2015 Accepted: 19 May 2016

Published online: 01 June 2016

\section{References}

Akkerman S, Van den Bossche P, Admiraal W, Gijselaers W, Segers M, Simons R-J, Kirschner P (2007) Reconsidering group cognition: From conceptual confusion to a boundary area between cognitive and socio-cultural perspectives? Educ Res Rev 2(1):39-63

Ashforth BE (2012) The role of time in socialization dynamics. In: Wanberg CR (ed) The Oxford handbook of socialization. Oxford University Press Inc, Oxford, pp 161-186

Bauer TN, Erdogan B (2012) Organizational socialization outcomes: now and into the future. In: Wanberg CR (ed) The Oxford handbook of organizational socialization. Oxford University Press, New York, pp 97-112

Bauer TN, Bodner T, Erdogan B, Truxillo DM, Tucker JS (2007) Newcomer adjustment during organizational socialization: a meta-analytic review of antecedents, outcomes, and methods. J Appl Psychol 92(3):707-721

Berweger S, Krattenmacher S, Salzmann P, Schönenberger S (2013) LiSa. Lernende im Spannungsfeld von Ausbildungserwartungen, Ausbildungsrealität und erfolgreicher Erstausbildung. Pädagogische Hochschule St. Gallen. Institut Professionsforschung und Kompetenzentwicklung, St. Gallen

Billett S (2000) Guided learning at work. JWL 12:272-285

Billett S (2002) Toward a workplace pedagogy: guidance, participation, and engagement. Adult Educ Q 53:27-43

Boomsma A (2000) Reporting analyses of covariance structures. Struct Equ Modeling 7(3):461-483

Büchter K, Kremer HH, Zoyke A (2014) Berufsorientierung als kontinuierliche Entwicklungsaufgabe-Eine empirische Studie über den Zusammenhang von Arbeitsbedingungen, Berufsbiographien und Berufsorientierung. bwp@ 27

Cable DM, Judge TA (1996) Person-organization fit, job choice decisions, and organizational entry. Organ Behav Hum Dec 67:294-311

de Saint-Georges I, Filliettaz L (2008) Situated trajectories of learning in vocational training interactions. Eur J Psychol Educ XXIII 2:213-233

Dornmayr H, Wieser R, Henkel S (2007) Einstiegsqualifikationen von Lehrstellensuchenden. Institut für Bildungsforschung der Wirtschaft, Wien 
Duncan TE, Duncan SC, Strycker LA (2006) An introduction to latent variable growth curve modeling: concepts, issues, and application. Lawrence Erlbaum Associates Inc, New York

Eccles JS (2005) Subjective task value and the Eccles et al. model of achievement-related choices. In: Elliot AJ, Dweck CS (eds) Handbook of competence and motivation. The Guilford Press, New York, pp 105-121

Ehrenthal B, Eberhard V, Ulrich JG (2005) Ausbildungsreife—auch unter den Fachleuten ein heißes Eisen. Bundesinstitut für Berufsbildung BiBB, Bonn

Filliettaz L (2010) Guidance as an interactional accomplishment practice-based learning within the Swiss VET system. In: Billett S (ed). Learning through practice: models, traditions, orientations and approaches, Amsterdam, pp 156-179

Hacker W, Skell W (1993) Lernen in der Arbeit. Bundesinstitut für Berufsbildung BIBB, Bonn

Haigh J (2007) Expansive learning in the university setting: the case for simulated clinical experience. Nurse Educ Pract $7(2): 95-102$

Herzog W, Neuenschwander MP, Wannack E (2006) Berufswahlprozess: Wie sich Jugendliche auf ihren Beruf vorbereiten. Haupt, Bern

Hinrichs A-C (2014) Predictors of collateral learning transfer in continuing vocational training. IJRVET 1(1):35-56

Hofmann C, Stalder BE, Tschan F, Häfeli K (2014) Support from teachers and trainers in vocational education and training: the pathways to career aspirations and further career development. IJRVET 1(1):1-20

Hu L-T, Bentler PM (1998) Fit indices in covariance structure modeling: sensitivity to underparameterized model misspecification. Psychol Methods 3(4):424-553

Hu L-T, Bentler PM (1999) Cutoff criteria for fit indexes in covariance structure analysis: conventional criteria versus new alternatives. Struct Equ Model 6(1):1-55

Irving PG, Meyer JP (1999) On using residual difference scores in the measurement of congruence: the case of met expectations research. Pers Psychol 52(1):85-95

Joardar A, Matthews LM (2010) An empirical investigation of group acceptance using the Big Five personality domains. OMJ 7(3):194-207

Kammeyer-Mueller JD, Wanberg CR (2003) Unwrapping the organizational entry process: disentangling multiple antecedents and their pathways to adjustment. J Appl Psychol 88(5):779-794

Kammeyer-Mueller JD, Wanberg CR, Rubenstein A, Song Z (2013) Support, undermining, and newcomer socialization: fitting in during the first 90 days. Acad Manag J 56(4):1104-1124

Klein HJ, Polin B (2012) Are organizations on board with best practices onboarding? In: Wanberg CR (ed) The Oxford handbook of socialization. Oxford University Press, New York, pp 267-287

Klotz VK, Billett S, Winther E (2014) Promoting workforce excellence: formation and relevance of vocational identity for vocational educational training. ERVET 6(1):1-20

Korte RF (2010) 'First, get to know them': a relational view of organizational socialization. HRDI 13(1):27-43

Kristof-Brown AL, Zimmerman RD, Johnson EC (2005) Consequences of individuals' fit at work: a meta-analysis of personjob, person-organization, person-group, and person-supervisor fit. Pers Psychol 58(2):281-342

Lamamra N, Duc B (2015) Die duale Berufsausbildung. In: Häfeli K, Neuneschwander MP, Schumann S (Hrsg.) Berufliche Passagen im Lebenslauf. Springer Fachmedien, Wiesbaden, D, S 101-126

Lapointe É, Vandenberghe C, Boudrias J-S (2014) Organizational socialization tactics and newcomer adjustment: the mediating role of role clarity and affect-based trust relationships. J Occup Organ Psychol 87(3):599-624

Masdonati J, Lamamra N (2009) La relation entre apprenti-e et personne formatrice au coeur de la transmission des savoirs en formation professionnelle. SZBW 31(2):335-353

Meyer T, Stalder BE, Matter M (2000) Bildungswunsch und Wirklichkeit. Bundesamt für Statistik (BFS), Schweizerische Konferenz der kantonalen Erziehungsdirektoren (EDK), Neuchâtel

Morrison EW (2002) Newcomers'relationships: the role of social network ties during socialization. Acad Manag J 45(6):1149-1160

Muthén LK, Muthén BO (1998-2012) Mplus. Statistical analysis with latent variables. User's guide. Muthén \& Muthén, Los Angeles

Nägele C, Neuenschwander MP (2014) Adjustment processes and fit perceptions as predictors of organizational commitment and occupational commitment of young workers. JVB 85(3):385-393

Nägele C, Neuenschwander MP (2015) Passt der Beruf zu mir? Determinanten und Konsequenzen wahrgenommener Passung mit dem Lehrberuf beim Übergang in die Berufsbildung In: Häfeli K, Neuenschwander MP, Schumann S (Hrsg) Berufliche Passagen im Lebenslauf. Springer Fachmedien, Wiesbaden, D, S 49-74

Negrini L, Forsblom L, Schumann S, Gurtner J-L (2015) Lehrvertragsauflösungen und die Rolle der betrieblichen Ausbildungsqualität. In: Häfeli K, Neuenschwander MP, Schumann S (Hrsg) Berufliche Passagen im Lebenslauf. Springer Fachmedien, Wiesbaden, S 77-99

Neuenschwander MP, Frank N (2009) Familie-Schule-Beruf FASE B. Dokumentation der Schülerbefragung Erhebung 2008. Fachhochschule Nordwestschweiz, Pädagogische Hochschule, Institut Forschung und Entwicklung, Zentrum Lernen und Sozialisation, Solothurn

Neuenschwander MP, Nägele C (2014) Sozialisationsprozesse beim Übergang in den Lehrbetrieb (SoLe). Schlussbericht im Auftrag des SBFI [Newcomer socialization in the training company in the transition from school to work. Final report]. Fachhochschule Nordwestschweiz, Pädagogische Hochschule, Institut Forschung und Entwicklung, Zentrum Lernen und Sozialisation, Solothurn

Neuenschwander MP, Böni E, Bärtschi S, Gerber U, Holder MC, Latscha C, Neumann M, Rauscher C, Schmid C, Wicki T (1998) Schule und Identität im Jugendalter I. Kurzdokumentation der Skalen und Stichproben. Universität Bern, Abteilung Pädagogische Psychologie, Bern

Neuenschwander MP, Gerber M, Frank N, Rottermann B (2012) Schule und Beruf: Wege in die Erwerbstätigkeit. VS Verlag für Sozialwissenschaften, Wiesbaden

Perrot S, Bauer TN, Abonneau D, Campoy E, Erdogan B, Liden RC (2014) Organizational socialization tactics and newcomer adjustment: the moderating role of perceived organizational support. GOM 39(3):247-273 
Rauner F, Akoojee S, Lerman RI, Smith E, WattMalcolm B, Zelloth H, Zhao Z (2000) Memorandum. An architecture for modern apprenticeships: standards for structure, organisation and governance. In: Deitmer L, Hauschildt U, Rauner F, Zelloth $\mathrm{H}$ (eds) The architecture of innovative apprenticeship: issues, concerns and prospects, vol 18. Springer, Dordrecht, pp 1-24

Saks AM, Gruman JA (2012) Getting newcomers on board: a review of socialization practices and introduction to socialization resources theory. In: Wanberg CR (ed) The Oxford handbook of socialization. Oxford University Press, New York

Schafer Y, Baeriswyl F (2015) Erfolg in der Berufsbildung. In: Häfeli K, Neuenschwander MP, Schumann S (Hrsg) Berufliche Passagen im Lebenslauf. Springer Fachmedien, Wiesbaden, D, S 127-160

Schafer JL, Graham JW (2002) Missing data: our view of the state of the art. Psychol Methods 7(2):147-177

Schallberger U, Häfeli K, Kraft U (1984) Zur reziproken Beziehung von Berufsausbildung und Persönlichkeitsentwicklung. ZSE 4:197-210

Schaubroeck JM, Peng AC, Hannah ST (2013) Developing trust with peers and leaders: impacts on organizational identification and performance during entry. Acad Manag J 56:1148-1168

Schmid E, Stalder BE (2012) Dropping out from apprenticeship training as an opportunity for change. In: Tynjälä P, Stenström M-L, Saarnivaara M (eds) Transitions and transformations in learning and education. Springer, Dordrecht, pp 117-130

Schmid M, Storni M (2004) Transition. Zur Qualifikation und Rekrutierung von Lehrlingen im Kanton Basel-Stadt. Ecce gemeinschaft für sozialforschung, Basel

SERI (2015) Vocational and professional education and training in Switzerland. Facts and figures 2015. State Secretariat for Education, Research and Innovation (SERI), Bern

Solinger ON, van Olffen W, Roe RA, Hofmans J (2013) On becoming (un)committed: a taxonomy and test of newcomer onboarding scenarios. Organ Sci 24(6):1640-1661

Sonnentag S (2012) Time in organizational research: catching up on a long neglected topic in order to improve theory. Psychol Rev 2(4):361-368

Spector PE, Fox S, Penney LM, Bruursema K, Goh A, Kessler S (2006) The dimensionality of counterproductivity: are all counterproductive behaviors created equal? JVB 68(3):446-460

Stalder BE (2000) Gesucht wird... Rekrutierung und Selektion von Lehrlingen im Kanton Bern. Amt für Bildungsforschung, Erziehungsdirektion des Kantons Bern, Bern

Stalder BE, Nägele C (2011) Vocational education and training in Switzerland: Organisation, development and challenges for the future. In: Bergman MM, Hupka-Brunner S, Keller AC, Meyer T (Hrsg) Seismo Verlag, Zürich, CH, S 18-39

Stalder BE, Nägele C (2015) Berufliche Identität, Commitment und Engagement. In: Fischer M, Rauner F, Zhao Z (Hrsg) Kompetenzdiagnostik in der beruflichen Bildung - Methoden zum Erfassen und Entwickeln beruflicher Kompetenz. LIT Verlag, Münster, S 259-273

Stalder BE, Schmid E (2006) Lehrvertragsauflösungen, ihre Ursachen und Konsequenzen. Ergebnisse aus dem Projekt LEVA. Bildungsplanung und Evaluation der Erziehungsdirektion des Kantons Bern, Bern

Stalder BE, Schmid E (2016) Lehrvertragsauflösungen und Ausbildungserfolg_kein Widerspruch. Hep-Verlag, Bern Stalder BE, Stricker C (2009) Traditionelle Arbeitstugenden sind nach wie vor zentral. Panorama 5:13-14

van de Schoot R, Lugtig P, Hox J (2012) A checklist for testing measurement invariance. Eur J Dev Psychol 9(4):486-492 van Vianen AEM, De Pater IE (2012) Content and development of newcomer person-organization fit: An agenda for future research. In: Wanberg CR (ed) The Oxford handbook of socialization. Oxford University Press, New York, pp 139-157

Vandenberg RJ, Scarpello V (1990) The matching model: an examination of the processes underlying realistic job previews. J Appl Psychol 75(1):60-67

Wenger E, McDermott R, Snyder WM (2002) A guide to managing knowledge. Cultivating communities of practice. Business School Publishing, Boston

\section{Submit your manuscript to a SpringerOpen ${ }^{\circ}$ journal and benefit from:}

- Convenient online submission

- Rigorous peer review

- Immediate publication on acceptance

Open access: articles freely available online

- High visibility within the field

- Retaining the copyright to your article

Submit your next manuscript at $>$ springeropen.com 